City University of New York (CUNY)

CUNY Academic Works

2014

Action Research, Assessment, and Institutional Review Boards (IRB): Conflicting Demands or Productive Tension for the Academic Librarian?

Robert Farrell

Lehman College, City University of New York

How does access to this work benefit you? Let us know!

More information about this work at: https://academicworks.cuny.edu/le_pubs/79

Discover additional works at: https://academicworks.cuny.edu

This work is made publicly available by the City University of New York (CUNY).

Contact: AcademicWorks@cuny.edu 


\begin{abstract}
This article puts forward an "assessment/action research/publication" cycle that integrates aspects of the assessment, research, and Institutional Review Board (IRB) processes to provide academic librarians with a systematic approach for balancing competing workplace demands and give library managers a roadmap for creating a "research culture" (Jacobs, Berg, and Cornwall) within their libraries. The article argues that librarians and library managers have much to gain by integrating action research into librarians' everyday work loads, including increased ease in meeting publication demands for tenure and/or promotion, institutionalizing habits of reflective practice across all library service areas, and overall library improvement.
\end{abstract}

\title{
Action Research, Assessment, and Institutional Review Boards (IRB): Conflicting Demands or Productive Tension for the Academic Librarian?
}

Tenure-track and other academic librarians in positions that require publication for promotion or advancement often find themselves in a difficult situation. The "publish or perish" rule holds true for these librarians just as much as for their colleagues in the disciplines. But unlike disciplinary faculty, librarians must typically find time to develop scholarship on twelve- rather than nine-month academic work calendars. To cope with these demands librarians may wish to turn to action research to develop scholarship grounded in their everyday work lives — research they're already informally conducting as a part of their reflective practice or as part of campus assessment requirements. But in so doing, their work must often be brought under the scope of Institutional Review Board 
(IRB) standards governing research conducted with human subjects, which may be extraneous to or even conflict with the basic goal of performance improvement and action research (DeTardo-Bora). To make matters more complicated, many if not most academic librarians do not have formal training in research methods (Eldredge) or experience with IRB (Smale; Labaree). They must, as a result, find time to acquaint themselves with and navigate the IRB process and the potential complications it poses with respect to action research.

This article puts forward an "assessment/action research/publication" cycle that integrates what the often disparate aspects of outcomes or programmatic assessment, research, and IRB processes in order to provide academic librarians with a systematic approach for balancing competing workplace demands. It will also seek to provide library managers with a roadmap for creating a "research culture" (Jacobs, Berg, and Cornwall) within their libraries, one that helps staff meet the competing demands of their jobs in manageable ways. The author, whose job duties entail coordinating his library's learning outcomes assessment program, will offer his recent experiences conducting action research into the impact of social media outreach on information literacy instruction delivery as an illustration of the benefits of this cycle. While the author is an experienced practitioner of action research in the library classroom, he is a relative novice when it comes to IRB and research design. The article will therefore outline some of the bumps along the way that may arise for the novice researcher. This article can therefore be seen both as the result of and a call for action research into methods for integrating action research within the academic library environment. 


\section{Why Publish? Why Action Research?}

Publishing is often a part of many academic librarians' path towards tenure and/or promotion. Since the 1970s, academic librarians have found their tenure and/or promotion requirements more and more frequently tied to their production of scholarship, particularly peer-reviewed articles written for the library field (Lamothe 157). Moreover, Jacobs, Berg, and Cornwall note that expectations for librarians to contribute to the professional literature have increased in recent years, "due in part to the professional movement within libraries towards evidence-based librarianship as well as an increasing expectation for meaningful measures of libraries and the services they provide" (2).

However, the distribution of activities that comprise academic librarian workloads have not changed in response to increased research and publication demands. As Fox has shown in his study of Canadian academic librarians, librarians have relatively little time in proportion to their overall workload to develop scholarship. Similar constraints on scholarship have been identified for American academic librarians. Hill notes that her own institution, the University of Colorado at Boulder, at the time of her writing, formally stipulated that scholarship should be weighted equally in relation to "practiceof-profession" both for disciplinary faculty and librarians for tenure and promotion $40 \%$ each - with the remaining $20 \%$ of such decisions based on "service" performance (9). For many librarians, "practice-of-profession," librarianship, and service obligations comprise the majority of their work lives. Colleges and Universities often turn to librarians to fill campus committee slots given librarians', on-average, 40 hour workweeks and year-round campus presence. And librarians spend most of their 
workdays teaching, performing reference services, developing and maintaining their libraries' collections, and completing and overseeing other, specialized tasks (scheduling and directing staff, developing websites, managing finances, etc.).

To be sure, meeting publication requirements for tenure or promotion is not easy for any academic. But whereas faculty in the disciplines may be able to find some workload balance by writing on days and in hours they are not teaching or grading, or during holiday periods such as winter, spring, and summer breaks, librarians typically have two to four weeks of leave per year, sometimes slightly more, and are expected to work or take their limited leave during times when there are breaks in classes. Thus, if librarians are to overcome the natural barriers to publication, they must find a way to do so within the constraints of their workplace obligations.

Academic librarians have done so by intuitively realizing what Zinskie and Repman have formally noted, namely that action research can be a valuable and efficient way "to turn...everyday work into meaningful inquiry" (25). Wirth, Kelly, and Webster's 2010 study of the kinds of publications produced by Oklahoma State University librarians seems to bear out Zinskie and Repman's statement, finding that more than half of all articles written by librarians in that institution "fell into the Boyer classification of Application," or scholarship that "is directly working to communicate new approaches" to professional areas of practice, with the other half of publications falling "fairly evenly across the remaining three categories" used to classify academic articles: teaching, integration, and discovery (518). Whether we have formally articulated it to ourselves as a field, action research seems to be a natural fit for librarianship. 
Action research has been defined as "a systematic approach to investigation that enables people to find effective solutions to problems they confront in their everyday lives" (Stringer 1). Since its formalization in the 1940s, it has evolved into a complex of methods by which educators, social scientists, community developers, and those within organizations find new and better ways to achieve explicit or implicit outcomes or performance standards (Cassell and Johnson). Unlike scientific inquiry that seeks to find “objective," "generalizable," "reliable," and "valid" (Stringer 41) data to verify or disconfirm hypotheses, action research is designed to provide insight into what forms of specific practices might best help local populations existing under unique conditions achieve their ends in the everyday course of trying to meet them.

But the question remains as to where librarians are to find the time to engage in such inquiry. In my own practice, I've found that the increasing emphasis on assessment in higher education in general, and in academic libraries in specific, has added a new layer of responsibility to my workload, but one which has paradoxically yielded new efficiencies for meeting publishing requirements when combined with action research.

\section{Action Research and the Assessment Cycle}

Assessment, which can be defined as the systematic measurement of a program's or unit's effectiveness at achieving its stated outcomes, goals, or performance standards, has come to permeate all aspects of academic librarianship in the United States, primarily through the work of the Association of Research Libraries (ARL) and Association of 
College and Research Libraries (ACRL) over the past several decades (Kyrillidou and Cook). Assessment has been a part of the academic library landscape for many years by virtue of the increasingly important role of assessment in the accreditation and funding of higher education institutions in general. Higher education as a whole, including academic libraries, remains in the "age of assessment" and "accountability" (Ray), one whose history can be traced back to the "scientific management" movement of the 1960s and 70s (Ewell).

Moreover, assessment has come into greater focus and prominence in U.S. academic libraries over the past five years as a result of the ACRL's major Institute of Museum and Library Services (IMLS) funded "Value of Academic Libraries" (VAL) initiative and "seminal" "Standards for Libraries in Higher Education" document (ACRL Annual Report). The ACRL "Standards for Libraries in Higher Education" seek to set forth a programmatic approach for assessing and demonstrating the value of all "core roles and contributions of academic libraries" with respect to their larger institutions (ACRL Standards). The general principles and performance indicators outlined in the document describe goals and ideal outcomes for each major aspect of the library, from its use of space, to its management, to its educational role in the institution and the lives of an institution's students. Following the establishment of these standards, the VAL initiative has since staged a series of workshops on their use at major national library conferences across the United States and is enrolling dozens of libraries into a program called "LibValue" designed to acculturate libraries into what we might think of as a total assessment process (ACRL Research and Review Committee 311). 
While many in higher education have come to deplore the trend towards assessment and view it as but another aspect of the corporatization of higher education, it is nonetheless a reality that academic libraries increasingly feel pressure to measure their "impact" on student learning or contribution to larger institutional goals and to communicate their "value" to their institution, whether because they are required to by their larger institution or because they need to justify their budgets in the face of increasing austerity and competition for funding on campus. As a result, assessment has become part of the typical academic librarian's workload in one way or another. Tying action research to assessment activities is one way librarians might look to find efficiencies in the workplace to make the publication process more manageable. By investing time in completing a cycle of assessment followed by action research, librarians can generate scholarship out of already assigned duties and, simultaneously, develop a continuous process of "reflection in action" and "reflection on action," habits of reflective practice, that will yield new, more efficient approaches to everyday work activities (Schon 31).

Assessment is primarily outwardly focused - directed towards determining whether efforts deliver results - and has often been described as a four-part cycle. Linda Suskie, an important American figure in the assessment movement at the level of regional accreditation, has put forth a concise picture of the assessment cycle whose steps can be generalized as follows:

1. Define - Articulate goals/performance objectives 
2. Design - Identify (or create) a place where the program/activity allows those objectives to be met

3. Measure - Asses whether outcomes/performance objectives are being achieved by current methods.

4. Reflect - Consider implications of results and plan for improvement. (Generalized from Suskie 4)

Action research, by contrast, can be thought of as inwardly focused - concerned with determining what kinds of efforts or modes of service or instruction deliver the best results. As such, it can be adopted as a method for completing the assessment cycle when assessment activities indicate that outcomes are not being met. While assessment has at times been identified as a form of action research (Suskie 13), we might better think of it as a precursor to action research and consider action research as a complex set of additional steps in the assessment cycle or an appendix cycle unto itself.

What is the nature of the action research cycle and how can it be seen an extension of the assessment cycle? As Stringer's "Look, Think, Act” model for an "action research routine" makes clear, action research starts with looking for a "specified issue or problem" (8-9). McNiff and Whitehead's "action-reflection cycle" begins at a similar point with “observation” (9): 


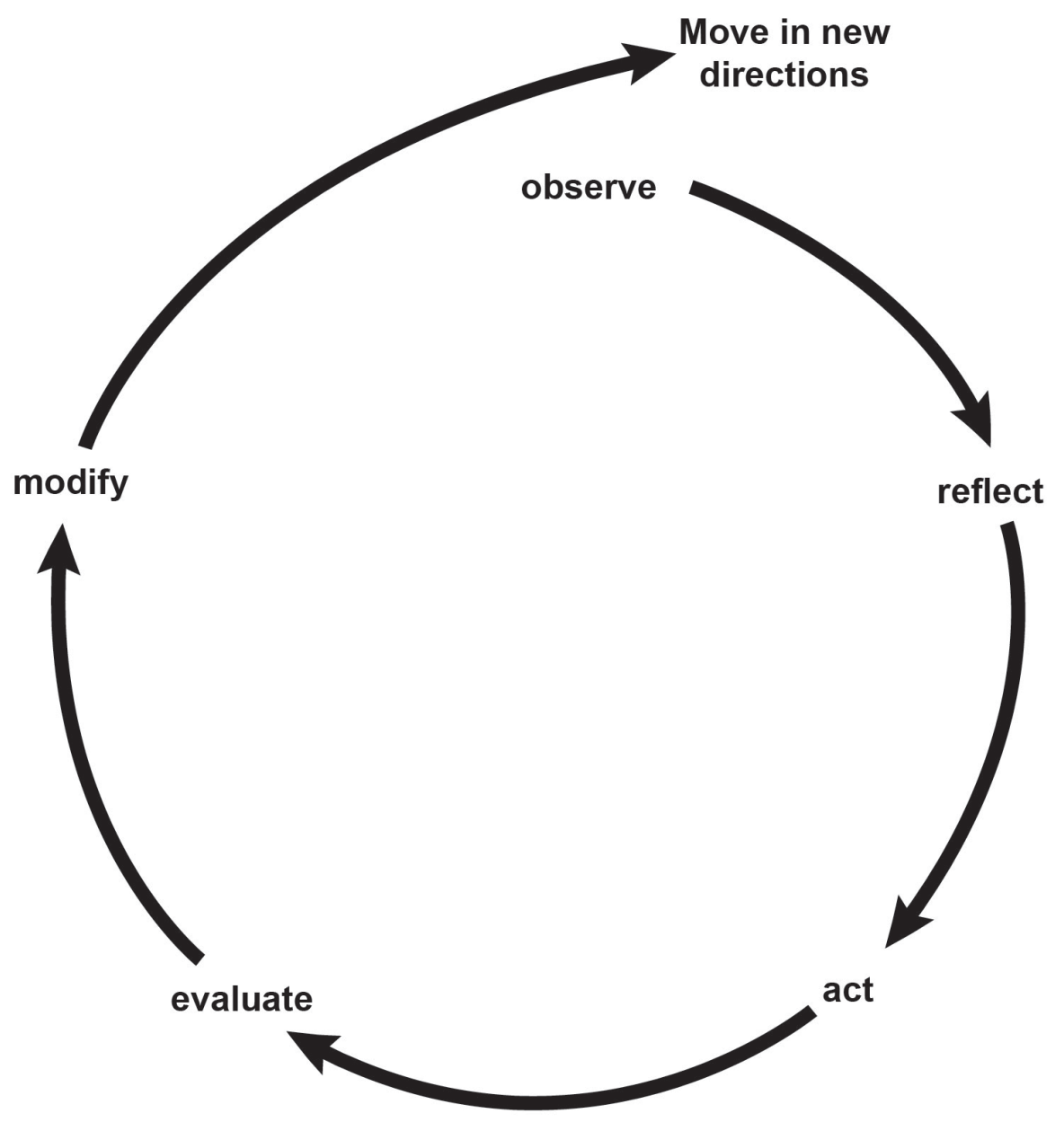

TITLE OF FIGURE 1: McNiff and Whitehead's action reflection cycle CITATION TO FIGURE: McNiff and Whitehead (9) 
The assessment process can thus be understood as the means towards clearly identifying the practical problem or concern - the focus - of action research, and action research as the means towards solving it. A picture of a cycle that brings assessment into relation with action research might look something like the following:

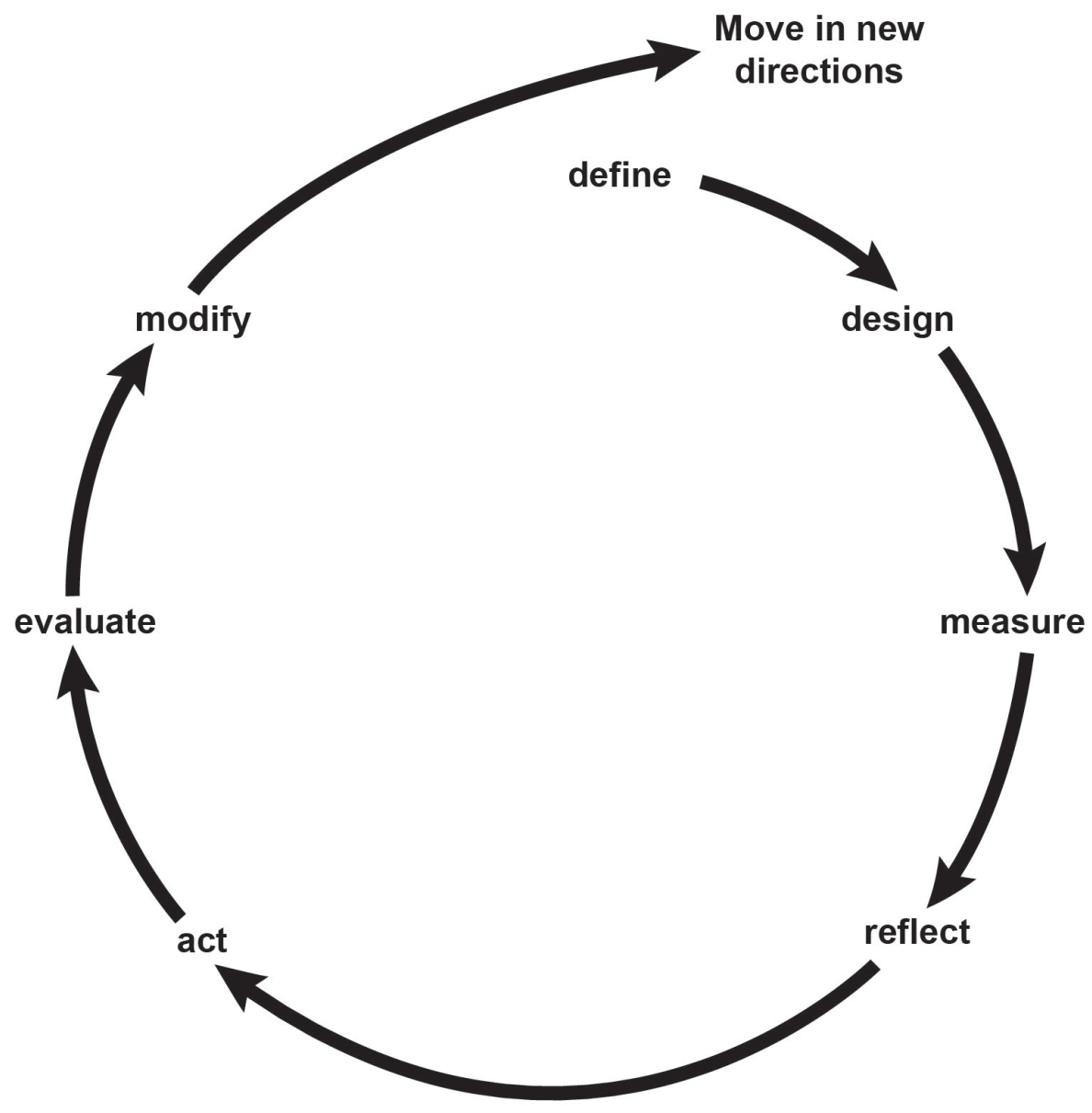

TITLE OF FIGURE 2: A combined assessment-action research cycle

CITATION TO FIGURE: Based on Suskie and McNiff and Whitehead. 
In this cycle, formal assessment processes dovetail directly into correlate action research, which then helps librarians spot opportunities for trying out new practical methods for improving the achievement of outcomes that are not being optimally met.

\section{Three Semesters and a Summer: A Sequence Towards Publication}

Thinking about assessment and action research as complementary activities affords academic librarians a clear path towards generating a publication grounded in action research. But how would this look in practice?

My own institution's assessment schedule requires the library's information literacy program to plan and execute two assessment projects per year, one each semester. We typically plan our assessments during the end of the summer prior to a new academic year, conduct our assessments and gather data during the semesters, then write the corresponding reports documenting our work in our next open window, typically early in the summer following the end of an academic year. Prior to engaging in the aforementioned inquiry into the effectiveness of social media outreach for information literacy instruction, we had already used our required assessment activities as opportunities to develop new pedagogical practices to solve problems brought to light through assessment. For example, during the spring of one academic year we determined that for a particular set of often delivered workshops, students were not meeting our learning expectations. The following spring, we made changes to various aspects of our instructional approaches and reassessed the same learning objectives and found that students were learning better due to our changes. But we had not capitalized on these activities to generate publications. While two semesters of work yielded two related 
reports, there seemed to be enough material to write an article if had we but obtained IRB approval and structured our activities slightly differently.

Recognizing the opportunity for developing publications presented by our assessment requirements, we focused attention on a third past assessment report, which pointed towards a need to develop new pedagogical techniques to prevent what the literature has called "satisficing." "Satisficing" in information literacy parlance has come to be used to refer to the process by which students find what they believe to be "good enough" information to complete a research assignment (Prabha et al). In our experience, this described well the kind of $11^{\text {th }}$-hour web-searching students were doing to complete research papers, despite having visited our library three times for workshops on finding better quality information through the use of the library's resources. We decided that if students were going to wait until the last minute to do their work, perhaps we could develop a form of $11^{\text {th }}$-hour pedagogy that would help our students "satisfice better," so to say. Over the summer, prior to the academic year, we planned to use our action research activities, which would take place in the spring, as the basis for our spring assessment report due to the college, but also decided that we would complete IRB training and obtain IRB approval for the study in order to publish or present our findings. We completed IRB training that summer and wrote up and submitted our IRB paperwork during the winter break.

In short, the approach we took to develop our assessment-action research sequence can be thought of as four blocks of time that can be broken into segments needed to assess, plan for action research, execute the action research, and write up one's findings. 


\section{Assess - Semester 1}

Plan - Obtain IRB Approval - Intersessions (summer after first semester and winter prior to second semester).

Execute - Semester 2

Write - Intersession (summer)

While this sequence allowed us to complete our assessment, action research, and IRB work, we did find that we felt quite rushed during the writing of our IRB paperwork and that the "two semesters and a summer" approach did not give us enough time to thoroughly plan and consider all of the complexities of our project. We therefore concluded that a "three semesters and a summer" structure might be more advantageous, at least to more novice academic librarian researchers:

Assess - Semester 1

Plan - Obtain IRB Approval - Semester 2 (and Intersessions as needed)

Execute - Semester 3

Write - Intersession (summer)

In coming semesters we plan on testing this approach to see if in fact it allows us to manage our time in a more measured way. While our two-semester approach did not lead us into serious errors, some of the unforeseen difficulties we encountered, which will be touched on below, could have perhaps been avoided with more time invested in the planning/IRB phase of our work. But, again, as we gain experience, a three-semester approach may prove more effective. It should be noted that the semesters in this 
suggested sequence need not be concurrent for the model to be effective. Our team of librarians conducted the initial assessment of student learning in the spring semester of one academic year and undertook the action research project in the spring of the following year, a sequence dictated by the schedule of our college's course offerings. And given our prior publication commitments, we are still waiting for a summer period in which we can develop our research into an article.

\section{Library-based Action Research and the Institutional Review Board Process}

If librarians intend to publish the results of their action research, IRB approval to conduct the study must be obtained in advance of any investigation. The act of publishing or otherwise promulgating any inquiry findings, based in practice or otherwise, brings up ethical issues of privacy related to anonymity and confidentiality as well as the potential for others to turn local, situated evidence into generalized knowledge. Most action research conducted within a library typically entails minimal risk for participants and falls under "exempt" or "expedited" categories of research that require less burdensome efforts and oversight than biomedical or other kinds of empirical, quantitative research.

Although the principles underlying the need for and process of IRB are fairly simple, many librarians, particularly "junior library faculty" or those "new to academic librarianship" can find the IRB process "daunting" (Smale 309). In recent years several articles (Smale; Labaree) have attempted to redress the lack of understanding of and preparation for IRB processes among librarians, but due to a variety of factors as outlined below, librarians still find it difficult. Complicating the IRB process is the very nature of 
action research itself, the goals of which, several scholars have argued, often conflict with IRB regulations aimed at protecting human subjects. After exploring some of these complications we will then offer a set of recommendations that may help library managers and librarians mitigate them.

\section{Librarians and IRB - Challenges to Consider}

Librarians' discomfort with IRB can be attributed to several factors. First, many graduate programs in library science and related fields that qualify students for professional librarianship do not have or do not require students to take a research methods course. Eldredge has noted that many library schools do not even have courses focused "on the strengths and weaknesses of major qualitative and quantitative research methods" (141). As a result, librarians entering their first positions in academic libraries often start at a publishing disadvantage when compared to their peers in the natural or social sciences.

Second, many librarians enter the field as a second career (Hardesty 88; Vega and Connell 505). Those entering academic librarianship from other areas of academia in which human subject research is common are able to adapt their skills to their new library positions. Those not from such backgrounds, which in the author's experience includes most new librarians transitioning from a prior career, may face a steep learning curve as they become socialized not only to research expectations, but to academia itself.

Last, many librarians are intimidated by the time commitment required to undertake a study under IRB. Typically, one must attend some sort of training, whether in person or virtually, and subsequently pass a test to demonstrate one's grasp of the 
principles of ethical research. While such training and testing is not on the face of it arduous, it does require the dedication of several hours. Adding to the length of time is the very activity of filling out the paper work and waiting for the Review Board's decision. Smale points out that as agencies that receive federal funding, most academic institutions choose to follow IRB guidelines fairly strictly. Failure to conduct research in an approved manner in any area of a college or university puts at risk the federal funding of the institution as a whole (311). As such, Institutional Review Boards have taken rather extraordinary, some would say extreme, measures to ensure that all research is thoroughly overseen (Sanders III and Ballengee-Morris 315). Foresight, careful planning, and persistence can mitigate the impact of a slow or persnickety board. But given the tight schedules librarians face on a daily basis, many may find the IRB review burdensome and not worth the effort if it is not efficiently managed as part of a larger process. We can only wonder how many interesting and innovative insights have been generated in the library field by librarians who've conducted action research but have not disseminated their findings in order to avoid IRB procedures.

\section{Action Research and IRB - Challenges to Consider}

As mentioned earlier, many scholars have noted that the goals of action research may come into conflict or tension with IRB processes (Stringer 91; Detardo-Bora; Lincoln and Tierney; Sanders III and Ballengee-Morris). The Belmont Report, as Smale points out, distinguishes between two kinds of studies - inquiry into "practice," which is defined by the report as "interventions that are designed solely to enhance the well-being of an individual patient or client and that have a reasonable expectation of success," and 
those that involve "research," which is defined as "an activity designed to test an hypothesis, permit conclusions to be drawn, and thereby to develop generalizable knowledge" (Smale 311). Inquiry into practice does not require those undertaking the inquiry to seek an IRB review of the ethics of the inquiry (Smale 311), but again, depending on the practices of the institution, researchers may not be at liberty to determine for themselves whether their work falls into this category.

But consider the following example: A Circulation Manager decides to inquire into the effectiveness of a new procedure to improve the efficiency of how staff charge and discharge electronic equipment at the library's circulation desk and would like to publish her findings. A number of questions arise. Would this be research-based inquiry or practice-based inquiry? And if it is research-based inquiry, does it fall into an exempt category per the definition of exempt studies under the Common Rule, the area of the U.S Code of Federal Regulations that formally articulates IRB standards for agencies receiving federal funding? Are "human subjects" involved in a way that warrants filling out more detailed paperwork for expedited or even full review? Certainly this example is far different from the kind of biological and psychological experimentation IRB review was primarily developed to evaluate and monitor. And as we have noted, action research is not based on testing hypotheses to arrive at scientific knowledge - it fundamentally "differs from positivist inquiry" (Detardo-Bora 240). The discoveries made are local discoveries related to the social conditions under which practice is performed.

But in this case, we can see that there are aspects of the inquiry that may bring it under IRB review. The fact that this study involves Circulation staff members who report to the Circulation Manager would, from an IRB perspective, make it necessary for the 
IRB to call for protection of the "human subjects" participating in the inquiry. The ethical issue is one of potential coercion of employees by supervisors, something that an IRB might cite to bring the study into a non-exempt category and require the primary investigator to provide participants with more protections in order to ensure that staff knowingly and willingly participate in the study.

A second area of potential conflict between action research and IRBs is the dynamic nature of the action research process. Detardo-Brora writes that action researchers often leverage multiple methodologies, "but they are employed in messy, real-world environments," which the researcher is attempting to "change...for the better" (243). Given that imperative, the action researcher may find it necessary to change tack in mid-sail and adopt a different methodological approach to problem solving when the original approach proves inadequate (Ibid.). Under IRB, such flexibility is almost impossible, as it would involve submitting a revised study design to document and seek approval for each change, a situation Detardo-Bora describes as a "researcher's nightmare" (248).

Moreover, the safeties put in place for obtaining "informed consent" from those involved in a study may actually end up inhibiting participation in the study. Action researchers "believe in research with people, rather than on people" (Rowan qtd. in Detardo-Bora 245). But a "positivist-oriented" IRB may not recognize that participants in action research play more of a co-investigative role in the course of finding solutions to community-based problems. The mandated use of a consent form in the course of action research may in some cases blur the "research with" versus "research on" distinction and be perceived by participants as "so intimidating that... [subjects] simply refuse to 
participate," thereby "frustrat[ing] a researcher's subject recruitment efforts" (Sanders III and Ballengee-Morris 316).

This turned out to be the case in our study of how we might use social media to address the student satisficing. For our outreach to have any effect, we knew students needed to put forth a reciprocal effort on the level of those of us conducting the outreach. But we were not able to achieve the kind of collaborative, participatory relationship with students that might make this possible, in great part, we believe, due to the effect of the consent form procedure. Having had no trouble getting students to friend us on Facebook and follow us on Twitter in the course prior instructional contact, we suddenly found students' reactions to these same requests, once we had presented them with a consent form, to be distinctly negative and even hostile. Students expressed worries about their online privacy in terms we had never previously encountered and librarians clarified that participating in the study would not allow librarians to violate their online privacy any more than friending or following anyone else they friend or follow would do. Moreover, several disciplinary faculty, who had given the librarians permission to undertake the study with their classes, explicitly made the point that participating in the study would simply give students additional opportunities to receive research help in the course of their writing. Despite these assurances about the safety and benefits of participating in our outreach, students remained suspicious of our motives and a majority chose not to participate at all. Clearly, students who in another context would have felt comfortable participating in our social media program, in this context felt as if they were vulnerable subjects. 
Our inexperience with IRB thus created a hurdle for us that made our action research more difficult than it might otherwise have needed to be, a situation not uncommon to other novice researchers. Those unaware, as we were at the time, of the potential pitfalls of using and presenting an informed consent form to the participatory "subjects" of a study risk alienating them and may not be able to arrive at useful, actionable results. The lack of full participation did not derail our inquiry, but in retrospect, had we known earlier what we later discovered through experience, we could have planned to make clear the participatory nature of the action research to our students and perhaps even checked with our IRB to see if we could receive an informed consent waiver that would have eliminated the issue altogether. Other novice researchers might make similar mistakes. For example, those who do not recognize that paperwork for an expedited or full rather than an exempt review is in order for a particular project might lose valuable time by completing the wrong paperwork and waiting for it to be reviewed.

It is here that more experienced library managers can step in to create programs and offer support that might help staff avoid the need to engage in a long trial and error learning process and it is to such managerial interventions that we will now turn our attention.

\section{Managing the IRB Process}

It should be clear that library managers have a direct interest in investing time and resources to equip staff with more sophisticated research skills. As such, library managers might consider formally integrating the study design and IRB paperwork completion processes into librarians' everyday, work-related duties. The model here put forward 
seeks to integrate action research into libraries' normal functioning as a way for libraries to become learning organizations. This can only happen if research is no longer viewed by senior library management as "something extra or added onto the regular work of librarians" (Jacobs, Berg, and Cornwall 7, emphasis original), but rather as an integral part of it. Library managers might best understand the time they provide staff to engage in the assessment/action research/IRB process as a direct investment in not only performance improvement, but in indirect benefits such as the professional development of staff and increased visibility of their libraries and larger institutions, among others (Perkins and Slowik 151-153). It is also an investment in organizational resilience. Citing Montanelli and Stenstrom, Mitchell and Reichel note that research activities generally feed back into library services, helping librarians develop new strategies to solve problems that arise in practice and, as a consequence, new capacities for adapting to change (233).

A number of possibilities open up to the library manager interested in fostering staff professional development in this area. First, library managers could consider encouraging or even requiring newly hired librarians to complete IRB training soon upon joining the library. While this may keep new librarians from immediately attending to other core tasks related to their position, there are numerous benefits to "frontloading" IRB training both for the individual librarian and the library as whole. Having an academic librarian complete IRB training early in his or her career puts the new librarian in a position to tackle IRB paperwork whenever an opportunity for action research arises in his or her practice. It also integrates the new librarian into the library's learning community and helps to position him or her to build collaborative relationships with 
more experienced researchers inside and, perhaps more importantly, outside the library (Montanelli and Stenstrom 483-484).

Second, library managers might recognize that staff very likely have little knowledge of what action research is and the variety of approaches to performance improvement it affords. An upfront investment of time and possibly money used to offer or send staff to professional development workshops in research methods may result in more efficient performance improvement and increased scholarship production among staff. For example, a library manager or director might pay for staff to view or attend a series of webinars or lectures on research methods. In the United States, professional academic organizations such as the New England Resource Center for Higher Education offer webinars on a variety of topics, including Participatory Action Research (New England Resource Center). Access to recorded sessions can often be purchased for a nominal fee from such organizations. Managers might also consider investing staff time in attending noted action research theorist Bob Dick's fourteen-week, online course in action research, which is free (Action Learning, Action Research Association), or other similar free of fee-based courses. The library manager might also try to take advantage of existing, available expertise on his or her own campus. For example, faculty members in fields whose research methods might be adapted to the library - e.g., education, or sociology - might be invited or even paid to provide lectures or workshops to librarians on topics related to action research. A campus assessment expert might be engaged to speak about methods for measuring improvement of typical library services. One could envision a number of such workshops or talks taking place over several years that, if 
recorded, would ultimately constitute a virtual course in research methods that could be referred back to or used to educate new hires into the research culture of the library.

The library manager might also support librarians in the development of a "journal club" that could regularly meet within work hours. Journal clubs are commonly found in labs and academic departments in the natural and health sciences and function to allow a lab, department, or group of practitioners to keep up with the research methodologies and findings of the field (Honey and Baker). While procedures vary from club to club, they typically meet on a regular basis, monthly or even weekly. each Members of the club summarize important articles, highlighting their salient points. One can envision how such a club might function within the academic library for and among researchers of differing experience levels. By analyzing and presenting on assessment oriented, action research, and other related articles, novice librarians would be able to gain insight into study design, methodological processes, and the common challenges librarians encounter when engaging in assessment and action research activities. More experienced librarians would find an efficient means for staying abreast of the field.

Finally, library managers and leaders within the profession might consider creating intensive learning opportunities in the area of action research and research methodologies in general along the lines of what the ACRL has done in the United States with its "Information Literacy Immersion" program. Now offering six tracks for four days of focused study on a variety of topics (ACRL Immersion), ACRL's Immersion program was founded in 1999 to address the professional development needs of those new to the profession in the area of information literacy instruction and teaching in libraries (Grugel and Copp). Analogous programs have been developed for other areas of 
practice, notably the Harvard Leadership Institute for Academic Librarians (Harvard Graduate School of Education), to develop leadership skills among professionals in the field. We've here identified a similar need for developing capacity among librarians for engaging in formal research. It may therefore be an opportune moment for library mangers and leaders in the profession to create formal "immersion" programs in the area of library assessment (beyond information literacy), action research and research methods in general. Kennedy and Brancolini's recent research into the professional development needs of librarians in the area of research design and their correlate IMLS grant-funded Institute for Research Design in Librarianship (IRDL) marks a positive first step in this direction for American librarians (Kennedy and Brancolini 439; Institute of Museum and Library Services). Beginning in the summer of 2014, IRDL will bring 21 librarians together every summer over three years (63 participants total) for nine days of intensive instruction in research design methods. Participants will leave the program with an implementable research project and will become part of a larger "community of researchers" established by the Institute over the three years of its work (Institute for Research in Librarianship). It can only be hoped that this initiative, developed through a partnership between Loyola Marymount University, San Jose State University School of Library and Information science, and the Statewide California Electronic Library Consortium, will find funds to continue operation. At the least, it will serve as a model for similar, needed professional development opportunities for the profession.

\section{Conclusion}


Many library managers may not be willing to make the immediate investment in staff to develop research capacity. Some may not see the value in taking busy staff out of their normal day-to-day duties to undertake training in research methods, however brief or beneficial such training may be. Others may not believe there is a "return on investment" to be gained by making the publication process an essential part of librarians' normal workload. In workplaces where research is not supported by senior library administrators, for whatever reason, librarians will need to plan carefully during all phases of the cycle here put forward to ensure themselves as efficient an experience as possible.

Librarians, for their part, might find that the IRB process in particular can, if handled properly, be a productive means for developing content for subsequent publications. In the process of articulating a research problem and describing one's methodology for IRB review forms, one is, in a sense, drafting elements that can be easily incorporated into an article. The more thorough one is in this stage, the more material one will have in the subsequent stages of research and writing. Moreover, as new librarians begin to fill out IRB review forms and gain IRB experience, it is likely that they will begin to conduct additional research into areas of practice related to those previously studied. IRB process efficiencies among all staff will be gained once there is a base of prior applications from which staff may draw. Staff might think about creating a "library" of past studies and IRB paperwork, the details of which can then be changed to meet the needs of new studies. Librarians in environments where research is not supported will need to develop an internal network of peer support to overcome some of the challenges they may face. 
The model put forward should therefore only be seen as a helpful, but not a foolproof path for balancing workload and scholarship. No model can avert the possibility that a novice researcher might discover that his or her approach to solving an initial problem was wrong from the start or that the necessary participants are unwilling to engage in the research. Nor can a model prevent the possibility that in the general crush of everyday tasks, an action plan developed to guide the intervention in practice might turn out to be inadequate to the task at hand. McNiff and Whitehead (89-130) provide thorough guidance for developing and executing an action research plan, but the advice they give and steps they outline, while simple, are not simplistic. A librarian, especially one new to research, may need to make several attempts at action research into a problem before a coherent plan and implementation process reveals itself. But for both the librarian and library manager committed to performance improvement and staff development, bringing together assessment, action research, and IRB training into a systematic process across all aspects of academic library activities can provide substantial benefits. Not only can it “[support] librarians' research endeavors” (Jacobs, Berg, and Cornwall 3) by providing staff with research topics that can be brought to fruition as publications as need arises, it can also help engender a reflective research culture, one in which research is integrated into librarians' everyday practice. 


\section{Works Cited}

ACRL. “Annual Report 2011-2012.” College \& Research Libraries News 73.11 (2012): 671-709.

-------. "Immersion Program." (2014). Web.

$<$ http://www.ala.org/acrl/immersionprogram $>$.

-------. "Standards for Libraries in Higher Education." (2011). Web.

$<$ http://www.ala.org/acrl/standards/standardslibraries $>$.

ACRL Research and Review Committee. "2012 Top Ten Trends in Academic Libraries." College and Research Libraries News 73.6 (2012): 311-320.

Action Learning, Action Research Association (ALARA). “Action Research and Evaluation Online Course (Areola).” (2014). Web. $<$ http://www.alarassociation.org/pages/education $>$.

Cassell, Catherine, and Phil Johnson. "Action research: Explaining the Diversity." Human Relations 59.6 (2006): 783-814

Detardo-Bora, Kimberly A. “Action Research in a World of Positivist-oriented Review Boards.” Action Research 2.3 (2004): 237-253. 
Eldredge, Jonathan D. "The Evolution of Evidence Based Library and Information Practice, Part I: Defining EBLIP.” Evidence Based Library and Information Practice 7.4 (2012): 139-145.

Ewell, Peter T. “An Emerging Scholarship: A Brief History of Assessment.” Building a Scholarship of Assessment. Ed. Trudy W. Banta. San Francisco: Jossey-Bass, 2002: $3-25$

Fox, David. "The Scholarship Of Canadian Research University Librarians.” Partnership: The Canadian Journal Of Library \& Information Practice \& Research 2.2 (2007): 1-25.

Grugel, Chris, and Madeline A. Copp. "Immersion '99: Reports From the Institute for Information Literacy Program." College \& Research Libraries News, 60.9 (1999): 723-728.

Hardesty, Larry L. "Future of Academic/Research Librarians: A Period of Transition -To What?" portal: Libraries and the Academy, 2.1 (2002): 79-97.

Harvard Graduate School of Education. "Leadership Institute for Academic Librarians." (2014). Web. $<$ http://www.gse.harvard.edu/ppe/programs/highereducation/portfolio/leadership-academic-librarians.html> . 
Hill, Janet Swan. "Constant Vigilance, Babelfish, and Foot Surgery: Perspectives on Faculty Status and Tenure for Academic Librarians." portal: Libraries and the Academy 5.1 (2005): 7-22.

Honey, Christopher P. and John A. Baker. "Exploring the impact of journal clubs: A systematic review." Nurse Education Today. 31.8 (2011): 825-831.

Institute for Research Design in Librarianship. “About IRDL.” (2014). Web. $<$ http://irdlonline.org/>.

Institute of Museum and Library Services. "IMLS Library Services September 2013 Grant Announcement.” (2013). Web. $<$ http://www.imls.gov/news/2013_ols_grant_announcement.aspx $>$.

Jacobs, Heidi L. M., Selinda Berg, and Dayna Cornwall. "Something To Talk About: ReThinking Conversations On Research Culture In Canadian Academic Libraries.” Partnership: The Canadian Journal Of Library \& Information Practice \& Research 5.2 (2010): 1-11.

Kennedy, Marie R., and Kristine R. Brancolini. “Academic Librarian Research: A Survey of Attitudes, Involvement, and Perceived Capabilities.” College \& Research Libraries 73.5 (2012): 431-448. 
Kyrillidou, Martha, and Colleen Cook. "The Evolution of Measurement and Evaluation of Libraries: A Perspective from the Association of Research Libraries." Library Trends 56:4 (2008): 888-909.

Labaree, Robert V. "Working Successfully With Your Institutional Review Board: Practical Advice For Academic Librarians." College \& Research Libraries News 71.4 (2010): 190-193.

Lamothe, Alain R. "The Importance of Encouraging Librarians to Publish in PeerReviewed Publications." Journal of Scholarly Publishing. 43:2 (2012): 156-167.

Lincoln, Yvonna S. and William G. Tierney. "Qualitative Research and Institutional Review Boards." Qualitative Inquiry 10:2 (2004): 219-234.

McNiff, Jean, and Jack Whitehead. All You Need to Know About Action Research. Thousand Oaks, CA: Sage, 2011.

Mitchell, W. Bede, and Mary Reichel. "Publish or Perish: A Dilemma For Academic Librarians?" College \& Research Libraries 60.3 (1999): 232-243.

Montanelli, Dale S., and Patricia F. Stenstrom. "The Benefits of Research for Academic Librarians and the Institutions They Serve.” College \& Research Libraries 47.5 (1986): 482-485. 
New England Resource Center for Higher Education. "Participatory Action Research (PAR): An Epistemology to Examine Purposes of Education.” (2014). Web. $<$ http://nerche.org/index.php?option=com_content\&view=article\&id=1376>.

Perkins, Gay Helen, and Amy J. Slowik. "The Value Of Research In Academic Libraries." College \& Research Libraries 74.2 (2013): 143-157

Prabha, Chandra, Lynn Silipigni Connaway, Lawrence Olszewski, and Lillie R. Jenkins. "What is enough? Satisficing information needs." Journal of Documentation 63.1 (2007): 74-89.

Ray, Kathlin L. "The Postmodern Library in an Age of Assessment." ACRL Tenth National Conference. Denver, CO. 15-18 March 2001. $<$ http://www.ala.org/acrl/sites/ala.org.acrl/files/content/conferences/pdf/kray.pdf $>$

Rowan, John. "Research Ethics.” International Journal of Psychotherapy 2.5 (2000): $103-112$.

Sanders III, James H. and Christine Ballengee-Morris. "Troubling the IRB: Institutional Review Boards' Impact on Art Educators Conducting Social Science Research 
Involving Human Subjects." Studies in Art Education: A Journal of Issues and Research 49.4 (2008): 311-327.

Schon, Donald A. "Knowing-in-Action: The New Scholarship Requires a New Epistemology.” Change 27.6 (1995): 26-34

Smale, Maura A. "Demystifying the IRB: Human Subjects Research in Academic Libraries." portal: Libraries and the Academy 10.3 (2010): 309-321.

Stringer, Ernest T. Action Research. Thousand Oaks, CA: Sage, 2014.

Suskie, Linda A. Assessing Student Learning: A Common Sense Guide. San Francisco, CA: Jossey-Bass, 2009.

Vega, Robert D. and Ruth S. Connell. “Librarians' Attitudes Toward Conferences: A Study." College \& Research Libraries 68.6 (2007): 503-516

Wirth, Andrea A., Maureen Kelly, and Janet Webster. “Assessing Library Scholarship: Experience At A Land Grant University.” College \& Research Libraries 71.6 (2010): 510-524.

Zinskie, Cordelia, and Judi Repman. "Getting Ready to Turn Your Everyday Work into Meaningful Inquiry: Foundational Literature in Qualitative and Action Research.” 
Using Qualitative Methods in Action Research: How Librarians Can Get to the

Why of Data. Ed. Douglas Cook and Leslie Farmer. Chicago: American Library Association, 2011. 25-32. 